\title{
Resistance of Potential Plant Growth Promoting Rhizobacteria to Heavy Metals (Ni, Cd, Co, Pb) Isolated from Polluted Areas of Hyderabad
}

\author{
M. Nissi Paul ${ }^{1 *}$, Sodimalla Triveni ${ }^{1}$, P.C. Latha $^{2}$, M. Chandini Patnaik ${ }^{3}$ \\ and A. Manohar Rao ${ }^{4}$ \\ ${ }^{1}$ Department of Agriculture Microbiology \& Bioenergy, ${ }^{4}$ Department of Horticulture, College \\ of Agriculture, PJTSAU, Hyderabad, India \\ ${ }^{2}$ Deparment of Microbiology, ICAR-Indian Institute of Rice Research, Hyderabad, India \\ ${ }^{3}$ AICRP on Micronutrients, Agriculture Research Institute, Hyderabad, India \\ *Corresponding author
}

\section{A B S T R A C T}

\section{Keywords}

PGPR activity,

Bacillus,

Rhizobium,

Minimal inhibitory

concentration,

Heavy

metal tolerance

Article Info

Accepted:

20 July 2018

Available Online:

10 August 2018
The toxicity and bioaccumulation tendency of heavy metals in the environment is a serious threat to the health of living organisms. Unlike organic contaminants, heavy metals cannot be broken down by chemical or biological processes. Hence, they can only be transformed into less toxic species. The present study was conducted to isolate promising heavy metal tolerant bacteria from various industrial polluted areas of Hyderabad, India and was tested for their plant growth promoting characteristics. Eleven strains isolated were identified as Bacillus (6) and Rhizobium (5) species and were tested for their maximum tolerance to heavy metals $(\mathrm{Ni}, \mathrm{Cd}, \mathrm{Co}, \mathrm{Pb})$ by supplementing its respective salts in different concentrations $(0,25,50,100,150$ and $200 \mathrm{mg} / \mathrm{l})$ to Nutrient agar and Yeast extract mannitol agar. Among all strains AfSB-1, SfSB-5, AfSR-1 andSfSR-4 were able to tolerate upto $100 \mathrm{mg} / \mathrm{l}$ concentration. All the isolates were also screened for various biochemical traits like, Mineral solubilisation ( $\mathrm{P}, \mathrm{K}, \mathrm{Zn}), \mathrm{HCN}$ production, IAA production, Siderophore production, EPS production ACC deaminase activity. The best strains with both metal tolerance and multifunctional traits will enrich the studies on genetic diversity and could be exploited for bioremediation of heavy metal polluted environment.

\section{Introduction}

Heavy metal pollution is increases day by day due to industrialization in all over world. Pollution is generated due to metallic ferrous ores mining and smelting, fossil fuels, sewage, municipal wastes, pesticides and fertilizers. The occurrence of these heavy metals in the environment has been a topic of great worry due to their toxicity, nonbiodegradable nature and the long biological half-lives for their removal from biological tissues (Aiking et al., 1984). Their high aquatic solubility triggers bioaccumulation and biomagnifications which eventually leads to insidious and irreversible health hazard 
(including potential carcinogenicity) even in very minimal concentration range of about 1 mg/l. Gupta and Diwan (2017).

Bioremediation is defined as the process by which microorganisms are stimulated to rapidly degrade hazardous organic pollutants to environmentally safe levels in ground water, soil, substances, materials and sediments. Recently, biological remediation process have also been devised to either precipitate effectively immobilize inorganic pollutants such as heavy metals. Stimulation of microorganisms is achieved by the addition of growth substances, nutrients, terminal electron acceptor or donors or some combination thereby resulting in an increase in organic pollutant degradation and biotransformation. The energy and carbon are obtained through the metabolism or organic compounds by the microbes involved in bioremediation processes. (Fulekar, 2009; Singh et al., 2014)

It is so necessary to separate bacterial strains with novel metabolic abilities and to start degradation pathways both biochemically and genetically. Screening out microbes from such an environment was done keeping in mind their multifunctional application especially for bioremediation. Among diverse soil microbes, plant-growth-promoting bacteria (PGPB) producing plant-growth regulators, mineral solubilizers, phytohormones, and various secondary metabolites have been reported to expedite the plant-growth and development and soothe plants against various environmental stresses including metal stress. Moreover, they have shown excellent results in reducing metal toxicity by promoting plant-growth when used as inoculants.

The aim of this study was to characterize metal tolerant microbial strains having plant growth promotion traits isolated from heavy metal contaminated soil and to recommend them as potential bioinoculants.

\section{Materials and Methods}

\section{Study area and collection of samples}

Heavy metal polluted soil and water samples were collected from three sewage irrigated agricultural sites (Afzalgung, Uppal, Student farm) in Hyderabad. Amount of heavy metals were also analyzed in water and soil samples by atomic absorption spectrophotometer (AAS) given by (Lindsay and Norway1978).

\section{Isolation, screening and characterisation of Heavy metal tolerant bacteria}

Qualitative characterization of all the eleven isolates were characterized by following standard protocols.

\section{Nitrogen fixing activity: Acetylene reduction assay}

The nitrogen fixing capacity of the test organisms were evaluated by using acetylene reduction assay following the standard procedure (Bergersen, 1980).

\section{Determination of Phosphate solubilization}

For estimation of phosphate solubilization all isolates were inoculated on the Pikovskaya's agar medium. After 3 to 5 days of incubation at $28 \pm 2{ }^{\circ} \mathrm{C}$, when bacteria solubilised the phosphate clear zone appear around the spot inoculums. Halo zone around the growth was measured for the obtaining the phosphate solubilisation.

\section{Production of Indole acetic acid}

Indole acetic acid production was quantitatively measured by the method given by Gordon and Weber (1951). Bacterial 
cultures were grown in a Luria-Bertani broth amended with tryptophan $(5 \mathrm{mM})$ for $3-4$ days. Cultures were centrifuged at 10,000 rpm for $20 \mathrm{~min}$. Two $\mathrm{ml}$ of supernatant was mixed with two drops of orthophosphoric acid and 4 $\mathrm{ml}$ of salkowski reagent. Tubes were incubated at room temperature for $25 \mathrm{~min}$. The intensity of pink color was red at $530 \mathrm{~nm}$ spectrophotometrically and the amount of IAA produced was extrapolated from the standard curve.

\section{Production of $\mathrm{HCN}$}

All the isolates were tested for the $\mathrm{HCN}$ production with the help of methodology of Castric and Castric (1983). A Whatman no.1 filter paper placed on lid of Petri plates and then autoclaved. Selected isolates were streaked on nutrient agar yeast extract mannitol agar plates amended with $4.4 \mathrm{~g} / \mathrm{l}$ of glycine.

Soaked the filter paper in $2 \%$ sodium bicarbonate and $0.5 \%$ picric acid solution and put inside the lid of the plates and sealed properly with parafilm and incubated for 3-4 days at $\pm 30^{\circ} \mathrm{C}$. $\mathrm{HCN}$ production is indicated by the appearance of color of filter paper from light brown to dark brown.

\section{Siderophore production}

Siderophore production was estimated qualitatively. By taking $0.5 \%$ of cell free culture supernatant and added to $0.5 \mathrm{ml}$ of $0.2 \%$ aqueous Ferric chloride solution. Appearance of orange or reddish brown colour indicated the presence of Siderophore (Yeole and Dube, 2000).

\section{EPS extraction}

The culture broth of all the isolates was centrifuged at $6000 \mathrm{rpm}$ for $10 \mathrm{~min}$ to remove cells. Two volumes of cold ethanol $\left(4^{\circ} \mathrm{C}\right)$ were added to the supernatant and the crude EPS precipitate was dried in a dessicator overnight (Rasulov et al., 2013).

\section{Screening for ACC deaminase activity}

All the heavy metal tolerant isolates were grown in $5 \mathrm{ml}$ of trypticase soy broth medium incubated at $28^{\circ} \mathrm{C}$ at $120 \mathrm{rpm}$ for $24 \mathrm{~h}$.

The cells were harvested by centrifugation at $3000 \mathrm{~g}$ for $5 \mathrm{~min}$ and washed twice with sterile $0.1 \mathrm{M}$ Tris- $\mathrm{HCl}(\mathrm{pH} 7.5)$ and spot inoculated on petri plates containing modified Dworkin and Foster salts minimal medium (Dworkin and Foster, 1958) supplemented with $3 \mathrm{mM}$ ACC as sole nitrogen source. Plates containing only DF salts minimal medium without ACC as negative control and with $\left(\mathrm{NH}_{4}\right)_{2} \mathrm{SO}_{4} \quad(0.2 \% \quad \mathrm{w} / \mathrm{v})$ as positive control. The plates were incubated at $28^{\circ} \mathrm{C}$ for $72 \mathrm{~h}$.

Growth of isolates on ACC supplemented plates was compared to negative and positive controls and was selected based on growth by utilizing ACC as nitrogen source.

\section{Metal tolerance test}

Heavy metals tolerant bacteria were isolated on nutrient agar and yeast extract mannitol agar supplemented with various concentration $(0,50,100,150$ and $200 \mathrm{mg} / \mathrm{l})$ of $\mathrm{NiCl}_{2} \cdot 6 \mathrm{H}_{2} \mathrm{O}$, $\mathrm{CdSO}_{4}, \mathrm{CoCl}_{2}$ and $\mathrm{PbCl}_{2}$.

The agar amended with heavy metal salts was sterilized at $121^{\circ} \mathrm{C}$ for $15 \mathrm{~min}$ and allowed to cool $40-45^{\circ}$ Cand transfer into petri plates. The pure cultures were streaked on heavy metal enriched medium and resistance was determined by the appearance of growth of bacteria after the 3 to 4 days of incubation.

The minimal inhibitory concentration (MIC) was determined as the lowest concentration of metal ion that completely inhibited growth. 


\section{Results and Discussion}

Initial heavy metal concentration of various polluted and unpolluted samples

The collected soil samples were prepared by drying and ground to pass through a $0.5 \mathrm{~mm}$ sieve. The heavy metals like Nickel (Ni), Cadmium $(\mathrm{Cd})$ Cobalt $(\mathrm{Co})$ and Lead $(\mathrm{Pb})$ in soil determined using DTPA method by Atomic absorption spectrophotometer given by (Lindsay and Norvell1978). Results showed that among the four heavy metals $\mathrm{Pb}$ was more ranging from $5.90-14.58 \mathrm{mg} / \mathrm{kg}$. The details of the Heavy metal concentrations were given in table 1 .

\section{Isolation and cultural characterization of} purified bacterial strains

A total of 28 bacterial isolates were isolated from soil and water by serial dilution and plate count method. These pure cultures of different bacterial isolates were preserved and carried out further analysis. The details of soil samples and bacterial codes were presented in table 2 .

The details of cultural and morphological characteristics of all the bacterial isolates were given in table 3. On Nutrient agar medium plates, a total of six Bacillus isolates showed dull to off white, irregular, non spreading smooth, flat, opaque, viscid colony characteristics. All the 6 isolates showed Gram positive reaction, rods with endospore formation, when observed under microscope

The colony morphology of isolates was examined on YEM agar plates. About five Rhizobium isolates showed small to medium, milky translucent, raised, mucoid colonies and formed non-spreading type of colonies. These pure cultures were checked for purity by streaking on different media like Hofer's alkaline agar, glucose peptone agar and lactose agar plates. None of the isolates showed any growth on these media plates.

\section{Multifunctional traits Bacillus and Rhizobium isolates for their PGPR characterization}

All the isolates show three or four traits of PGPR shown in the Table 4. Among all the eleven isolates 5 Bacillus and 1 Rhizobium isolates were able to form clear zone of phosphate solubilisation on Pikovyskaya's agar plate ranged from 5-13 mm. Among them SfS-4 recorded the highest solubilisation zone $(12.76 \mathrm{~mm})$ followed by AfS-2 (12.1 $\mathrm{mm})$.

Except one Bacillus strain (SfS-17) all bacterial strains were found to be positive for IAA production ranging in concentration from 1.50 to $21 \mu \mathrm{g} / \mathrm{ml}$ as determined by the development of pink color after reaction with Salkowski reagent. Rhizobium strain UpS-16 from YEMA plate and Bacillus strain SfSB-5 from nutrient agar plate showed highest IAA production $\left(21.51 \mu \mathrm{g} \mathrm{ml}^{-1}\right)$ and $(19.16 \mu \mathrm{g}$ $\mathrm{ml}^{-1}$ ) respectively with spectrophotometer readings.

The development of a mucoid aspect, indicating a possible EPS development by the strains; and more evident was by adding two volumes of cold ethanol $\left(4^{\circ} \mathrm{C}\right)$ to the supernatant. EPS production was shown by only three Rhizobium isolates AfS-15, UpS16 , and SfS-17 and only by twoBacillusAfSB1 , SfSB-5 isolates.

All the bacterial isolates were grown on DF salts minimal medium plus either ACC or ammonium sulphate and were assayed for ACC deaminase activity by incubating the extract with ACC and observing the growth. Four out of six Bacillus strains were positive for ACC deaminase activity; two isolates showed moderate $(++)$ ACCd production 
(AfSB-2 and SfSB-5), remaining two isolates showed weak $(+)$ ACCd production. Three out of five Rhizobium strains were grown on the enriched medium and utilised 1aminocyclopropane- 1-carboxylase as a sole nitrogen source, AfSR-15 and SfS-18 were moderate $(++)$ for ACCd, while UpS-17 and AfW-19 were week $(+)$ producers.

Isolated bacteria strains were examined for Hydrogen cyanide $(\mathrm{HCN})$ and Siderophore production. Nine among eleven were positive for $\mathrm{HCN}$ and their level of production was based on their change of filter paper from yellow to orangeAfS-1, SfS-5, SfS-18 were strong producers.

Siderophore production was shown by all the isolates and among them Rhizobium strain AfS- 15is the strong producers (+++); showed intense colour at the end. And most of them were moderate producers (++) AfS-1, UpS-3, SfS-4, SfS-17, SfS-18 and AfW-19.

\section{Assessment of MIC against each heavy metal}

Minimum inhibitory concentration (MIC) for each heavy metal was examined ranging from 25 to $200 \mathrm{mg} / \mathrm{L}$ given in Table 5 . Only four bacterial strains (AfS-1, SfS-5, AfS-15 and SfS-18) were resistant to higher concentration of Heavy metal salt (upto $100 \mathrm{mg} / \mathrm{l}$ ). Among 6 Bacillus isolates SfS-5 shown resistance to higher concentration (ie upto100 $\mathrm{mg} / \mathrm{l}$ of $\mathrm{Ni}$, Co; upto $150 \mathrm{mg} / \mathrm{l} \mathrm{Cd}$ and upto $200 \mathrm{mg} / \mathrm{l}$ of $\mathrm{Pb}$ ) and SfS-4 of Rhizobium isolates showed resistance (upto100 mg/l of $\mathrm{Ni}, \mathrm{Cd}$ and $\mathrm{Co}$ salts and upto $150 \mathrm{mg} / \mathrm{l}$ of $\mathrm{Pb}$ salt).

Table.1 Heavy metal concentration of various polluted samples (ppm)

\begin{tabular}{|c|c|c|c|c|}
\hline Samples & Nickel $(\mathrm{Ni})$ & Cadmium $(\mathrm{Cd})$ & Cobalt $(\mathrm{Co})$ & Lead $(\mathrm{Pb})$ \\
\hline Afzulgung soil & 3.16 & 1.01 & 2.55 & 8.56 \\
\hline Uppal soil & 2.98 & 1.98 & 1.59 & 12.61 \\
\hline Student farm soil & 3.11 & 1.23 & 1.62 & 14.58 \\
\hline Afzulgung water & 2.61 & 0.54 & 0.86 & 5.90 \\
\hline Uppal water & 2.35 & 0.95 & 0.42 & 6.95 \\
\hline $\begin{array}{c}\text { Student farm } \\
\text { water }\end{array}$ & 2.54 & 0.87 & 0.53 & 9.32 \\
\hline
\end{tabular}

Table.2 Isolated and purified bacterial strains from different sources

\begin{tabular}{|c|c|c|}
\hline Sampling source & $\begin{array}{c}\text { Number of bacterial } \\
\text { isolates }\end{array}$ & Codes of Isolates \\
\hline Afzalgung soil & 3 & AfS-1, AfS-2, AfS-15 \\
\hline Uppal soil & 2 & UpS-3, UpS-16 \\
\hline Student farm soil & 4 & SfS-4, SfS-5, SfS-17, SfS-18 \\
\hline Afzalgung water & 1 & AfW-19 \\
\hline Student farm water & 1 & SfW-6 \\
\hline
\end{tabular}


Table.3 Morphological and cultural characteristics of Bacillus and Rhizobiumisolates

\begin{tabular}{|c|c|c|c|c|}
\hline \multicolumn{2}{|c|}{ Isolates } & \multirow{2}{*}{$\begin{array}{c}\text { Gram } \\
\text { reaction } \\
\text { +ve }\end{array}$} & \multirow{2}{*}{$\begin{array}{c}\text { Cell } \\
\text { Shape } \\
\text { Rod }\end{array}$} & Colony characteristics \\
\hline \multirow{6}{*}{ Bacillus } & AfSB-1 & & & $\begin{array}{l}\text { Dull white, irregular, spreading, smooth, flat, opaque, } \\
\text { undulate margin }\end{array}$ \\
\hline & AfSB-2 & + ve & Rod & $\begin{array}{c}\text { Off white, irregular, non-spreading, smooth, flat, opaque, } \\
\text { undulate margin, viscid colony }\end{array}$ \\
\hline & UpSB-3 & + ve & Rod & $\begin{array}{l}\text { Dull white, irregular, spreading, smooth, flat, opaque, } \\
\text { undulate margin }\end{array}$ \\
\hline & SfSB-4 & + ve & Rod & $\begin{array}{c}\text { Dull white, irregular, large, smooth, flat, opaque, } \\
\text { undulate margin, viscid colony }\end{array}$ \\
\hline & SfSB-5 & $+\mathrm{ve}$ & Rod & $\begin{array}{c}\text { Off white, irregular, non-spreading, smooth, flat, opaque, } \\
\text { undulate margin, viscid colony }\end{array}$ \\
\hline & SfWB-6 & $+\mathrm{ve}$ & Rod & $\begin{array}{c}\text { Dull white, irregular, spreading, smooth, flat, opaque, } \\
\text { undulate margin }\end{array}$ \\
\hline \multirow{5}{*}{ Rhizobium } & AfSR-1 & -ve & Rod & $\begin{array}{l}\text { Gummy white, round, non-spreading, smooth, raised, } \\
\text { transluscent, mucoid colony }\end{array}$ \\
\hline & UpSR-2 & -ve & Rod & $\begin{array}{l}\text { Gummy white, round, non-spreading, smooth, raised, } \\
\text { transluscent, mucoid colony }\end{array}$ \\
\hline & SfSR-3 & -ve & Rod & $\begin{array}{l}\text { Gummy white, round, non-spreading, smooth, raised, } \\
\text { transluscent, mucoid colony }\end{array}$ \\
\hline & SfSR-4 & -ve & Rod & Gummy white, flat, entire, wrinkled edge \\
\hline & AfWR-5 & -ve & Rod & Flat, entire, wrinkled edge \\
\hline
\end{tabular}

Table.4 Multiple plant growth promoting activities of Bacillus and Rhizobium isolates from the Heavy metal polluted soil

\begin{tabular}{|c|c|c|c|c|c|c|c|}
\hline Isolates & $\begin{array}{c}\mathrm{PO}_{4} \\
\text { Solubilisation(mm) }\end{array}$ & $\begin{array}{c}\text { Nitrogenase activity- } \\
\mathrm{ARA}\left(\mathrm{nmol} \mathrm{C}_{2} \mathrm{H}_{4} \mathrm{mg}\right. \\
\left.\mathrm{protein}^{-1} \mathrm{~h}^{-1}\right)\end{array}$ & $\begin{array}{c}\text { IAA } \\
\text { Production } \\
\left(\mu \mathrm{ml}^{-1}\right)\end{array}$ & $\begin{array}{c}\text { EPS } \\
\text { Production }\end{array}$ & $\begin{array}{c}\text { ACC } \\
\text { deaminease }\end{array}$ & $\begin{array}{c}\mathrm{HCN} \\
\text { Production }\end{array}$ & $\begin{array}{l}\text { Siderophore } \\
\text { Production }\end{array}$ \\
\hline AfS-1 & 10.3 & $\mathrm{ND}$ & 16.00 & ++ & + & +++ & ++ \\
\hline $\mathbf{A f S}-2$ & 12.1 & $\mathrm{ND}$ & 9.38 & - & ++ & ++ & + \\
\hline $\mathbf{U p S - 3}$ & - & $\mathrm{ND}$ & 18.21 & - & - & - & ++ \\
\hline $\mathbf{S f S}-4$ & 12.76 & 0.18 & 1.51 & - & - & ++ & ++ \\
\hline SfS-5 & 09.33 & $\mathrm{ND}$ & 19.16 & + & ++ & +++ & + \\
\hline SfW-6 & 08.00 & $\mathrm{ND}$ & 5.81 & + & + & - & + \\
\hline AfS-15 & 4.11 & 2.20 & 19.03 & + & ++ & + & +++ \\
\hline UpS-16 & - & 2.16 & 21.51 & ++ & + & + & + \\
\hline SfS-17 & - & 4.23 & - & ++ & - & + & ++ \\
\hline SfS-18 & 8.78 & 4.54 & 16.34 & ++ & ++ & +++ & ++ \\
\hline AfW-19 & - & 2.66 & 12.44 & - & - & + & ++ \\
\hline
\end{tabular}


Table.5 Heavy metal tolerance of Bacillus and Rhizobium spp

\begin{tabular}{|c|c|c|c|c|}
\hline \multicolumn{7}{|c|}{ HEAVY METAL TOLERANCE $(\mathrm{mg} / \mathrm{l})$} \\
\hline Isolates & $\mathbf{N i}$ & $\mathbf{C d}$ & $\mathbf{C o}$ & $\mathbf{P b}$ \\
\hline $\mathbf{A f S}-1$ & 100 & 100 & 100 & 150 \\
\hline $\mathbf{A f S}-2$ & 50 & 50 & 100 & 150 \\
\hline UpS-3 & 25 & 50 & 25 & 100 \\
\hline SfS-4 & 50 & 100 & 50 & 150 \\
\hline SfS-5 & 100 & 150 & 100 & 200 \\
\hline SfW-6 & 100 & 50 & 50 & 100 \\
\hline AfS-15 & 100 & 100 & 100 & 100 \\
\hline UpS-16 & 50 & 150 & 50 & 100 \\
\hline SfS-17 & 25 & 100 & 25 & 100 \\
\hline SfS-18 & 100 & 100 & 100 & 150 \\
\hline $\mathbf{A f W}-19$ & 100 & 50 & 50 & 100 \\
\hline
\end{tabular}

The Bacillus and Rhizobium strains isolated from the heavy metal polluted soils showed resistance to $25 \mathrm{mg} / \mathrm{l}$ concentration of heavy metals with at least three PGPR activities. Research reports suggested that diverse group of free-living soil bacteria can improve host plant growth and alleviate toxic effects of heavy metals on the plants (Belimov et al., 2004; Wani et al., 2008). Pandey et al., (2011) isolated and characterized two $\mathrm{Pb}$ and arsenate tolerant Bacillus sp. from slag disposal site. Similar type of results reported by Singh et al., (2015) isolated Bacillus safensisKM39 (LT) and evaluated for plant growth promoting traits, Heavy metal $(\mathrm{Pb}$ and $\mathrm{Cd}$ ) resistance and bioaccumulation of heavy metals and showed positive results for qualitative parameters viz. inorganic Phosphate solubilization, production of siderophores, Indole acetic acid, HCN and ammonia production.

Wani and Khan (2012) isolated Rhizobium strain RL9 from the nodules of lentil grown in metal contaminated soils. The strain tolerated $\mathrm{Pb}$ upto a concentration of $1600 \mu \mathrm{g} / \mathrm{ml}$. It also produced a good amount of IAA which found to produce a maximum amount of $33 \mu \mathrm{g} / \mathrm{ml}$ of IAA at $100 \mu \mathrm{g} / \mathrm{ml}$ of tryptophan. Similar type of results was reported by Wani et al., (2008), they isolated nickel and zinc-tolerant plant growth-promoting (PGP) Rhizobium sp. RP5 from nodules of pea, grown in metalcontaminated Indian soils. Strain RP5 displayed a high level of tolerance to nickel $\left(350 \mu \mathrm{g} \mathrm{ml}^{-1}\right)$ and zinc $\left(1500 \mu \mathrm{g} \mathrm{ml}^{-1}\right)$ and showed PGP activity like nitrogen fixation, growth promotion, and the ability to reduce the toxicity of nickel and zinc under in vitro conditions and reported their importance in augmenting the growth and yield of pea, in nickel- and zinc-polluted soils.

In conclusion, the study has been done is demonstrated that microorganism are helpful for reduction of leaching of heavy metals in environment. Hence, we can use these isolates for minimization of toxicity and enhancement of plant growth by its PGPR activity even under metal stress condition. This study is also helpful for bioremediation because of high level of MIC of isolates. 


\section{Acknowledgement}

We give glory to God for the blessings bestowed upon us. We are thankful to the Department of Agricultural Microbiology, College of Agriculture, PJTSAU Rajendranagar, Hyderabad for providing all facilities for conducting the research work.I am also thankful to P. John Alex for the financial assistance during my research work.

\section{References}

Aiking H, Stijnman AC, Garderen V, Heerikhuizen HV, Riet J VT (1984) Inorganic phosphate accumulation and cadmium detoxification in Klebsiella aerogenes NCTC 418 growing in continuous culture. Applied Environmental Microbiology 47: 374 377.

Belimov, A. A., Kunakova, A.M., Safronova, V.I., Stepanok, V.V., Yudkin, L.Y., Alekseev, Y.V and Kozhemyakov, A.P.2004. Employment of rhizobacteria for the inoculation of barley plants cultivated in soil contaminated with lead and cadmium. Microbiology (Moscow) 73(1):99-106.

Bergerson, F.J. 1980. Methods for evaluating biological nitrogen fixation. John Wiley and sons, New York. Pp. 702.

Castric, K.F and Castric, P.A. 1983. Method for rapid detection of cyanogenic bacteria. Applied and Environmental Microbiology.45: 700-702.

Dworkin, M and Foster, J. 1958. Experiments with some microorganisms which utilize ethane and hydrogen. Journal of Bacteriology. 75: 592-601.

Gorden, A.S and Weber, R.P. 1951. Colorimetric estimation of Indole acetic acid. Plant Physiology. 26: 192-195.

Gupta. P and Diwan. B 2017. Bacterial Exopolysaccharide mediated heavy metal removal: A Review on biosynthesis, mechanism and remediation strategies Biotechnology Reports 13: 58-71

Khan, A. G. (2005) Role of soil microbes in the rhizospheres of plants growing on trace metal contaminated soils in phytoremediation. Journal of Trace Elements in Medicine and Biology: Organ of the Society for Minerals and Trace Elements (GMS), 18, 355-364.

Lindsay, W.L and Norvell, W.A. 1978. Development of DTPA soil test for zinc, iron, manganese and copper. Soil Science Society of American Journal.41:421-428.

M.H. Fulekar, Bioremediation of fenvalerate by Pseudomonas aeruginosa in a scale up bioreactor, Romanian Biotechnological Letters, 14(6), 2009, 4900-4905.

Pandey, S., Saha, P., Biswas, S and Maiti, T.K. 2011. Characterization of two metal resistant Bacillus strains isolated from slag disposal site at Burnpur, India, Journal of environmental Biology. 32, 773-779.

Rasulov, B A., Yili, A and Aisa, H.A. 2013 Biosorption of Metal Ions by Exopolysaccharide Produced by AzotobacterchroococcumXU1 Journal of Environmental Protection (4) 989993

Singh, R., Pathak, B and Fulekar, M.H. 2015. Characterization of PGP Traits by Heavy Metals Tolerant Pseudomonas putida and Bacillus safensis Strain Isolated from Rhizospheric Zone of Weed (Phyllanthus urinaria) and its efficiency in $\mathrm{Cd}$ and $\mathrm{Pb}$ Removal. International Journal of Current Microbiology and Applied Sciences. 4(7): 954-975.

Singh, R.P. Singh, R. Sharma. 2014. Microorganism as a tool of bioremediation technology for cleaning environment: A review, International 
Academy of Ecology and Environmental Science, 4 (1):1-6.

Tchounwou, P.B., Yedjou, C.G., Patlolla, A.K., Sutton, D.J. 2012. Heavy Metal Toxicity and the Environment. In Molecular, Clinical and Environmental Toxicology, Springer, 133-164.

Wani PA., Khan, M. D and Zaidi, A. 2008. Effect of Metal-Tolerant Plant GrowthPromoting Rhizobium on the Performance of Pea Grown in MetalAmended. Archives of Environmental
Contamination and Toxicology. 55(1):33-42.

Wani, P.A and Khan, M.S. 2012. Bioremediation of Lead by a Plant Growth Promoting Rhizobium Species RL9.Bacteriology Journal2 (4): 66-78.

Yeole, R.D., Dube, H.C. 2000. Siderophore mediated antibiosis of rhizobacterial fluorescent Pseudomonas against certain soil borne fungal plant pathogens. Journal of Mycology and Plant Pathology.30 (3): 335-338.

\section{How to cite this article:}

Nissi Paul, M., Sodimalla Triveni, P.C. Latha, M. Chandini Patnaik and Manohar Rao, A. 2018. Resistance of Potential Plant Growth Promoting Rhizobacteria to Heavy Metals (Ni, Cd, $\mathrm{Co}, \mathrm{Pb}$ ) Isolated from Polluted Areas of Hyderabad. Int.J.Curr.Microbiol.App.Sci. 7(08): 35833591. doi: https://doi.org/10.20546/ijcmas.2018.708.362 